\title{
Kombinasi Metode AHP dan VIKOR Untuk Pemilihan Santri Berprestasi
}

\author{
Mohammad Fauzi, Mujib Ridwan, Khalid
}

\begin{abstract}
This research attempts to do selection for an excelling student in a Mambaul Hikam boarding school. It will take for recommendation for joining Program Beasiswa Santri Berprestasi (a legacy of student scholarship program), can be called PBSB. Before doing the research, Mambaul Hikam boarding school has no any recommendation for the students for joining PBSB. At this time, the students join PBSB take them who only wants to registered, then the school administration take the student for following the test that will be held by the ministry of religion. To make it easier for the school to obtain the name of the students who get the achievement, a Decision Support System for selecting the excelling student is built. Through the system, the school administration can input the data of the students such as the score and the criteria value. The system will give recommendation for the names of the student who has achievement by using AHP and VIKOR method. The both method are combined, AHP is for calculate the criteria value and VIKOR is for doing alternative ranking for the score. Using both the methods aim to complement each other's deficiencies. System testing uses a black box, vikor sensitivity test, accuracy, recall, and precision. The test was done by using the data of the students in 2015- 2016 in science and social major. Based on the vikor sensitivity test, it is conclude that alternative student with NIS 150106 and 150129 have sensitivities changing when the variable of the value $V$ is changed by using 0,4 and 0,6 . The results of the average data by the test accuracy are $90,5 \%$, the recall value is 87 , $5 \%$, and the precision value is $35 \%$.
\end{abstract}

Index Terms-AHP, the excelling student, DSS, VIKOR.

Abstrak--Penelitian ini mencoba melakukan seleksi pemilihan santri berprestasi, yang nantinya akan direkomendasikan juga untuk mengikuti Program Beasiswa Santri Berprestasi, biasa disingkat PBSB. Sebelumnya di Pondok Pesantren Manbaul Hikam belum ada rekomendasi nama santri untuk mengikuti PBSB. Untuk saat ini, santri mengikuti PBSB hanya sebatas siapa yang ingin mendaftar, kemudian pihak sekolah mengantarkannya untuk mengikuti tes yang diadakan

Mohammad Fauzi, Program Studi Sistem Informasi Fakultas Sains dan Teknologi UIN Sunan Ampel Surabaya, Indonesia (email: fauzimohammad97@gmail.com)

Mujib Ridwan, Program Studi Sistem Informasi Fakultas Sains dan Teknologi UIN Sunan Ampel Surabaya, Indonesia (email: mujibrw@uinsby.ac.id)

Khalid, Program Studi Sistem Informasi Fakultas Sains dan Teknologi UIN Sunan Ampel Surabaya, Indonesia (email: khalid@uinsby.ac.id) oleh Kemenag. Untuk memudahkan pihak sekolah dalam memperoleh nama - nama santri berprestasi, maka dibangunlah sistem pendukung keputusan pemiliihan santri berprestasi. Melalui sistem, pengguna dapat menambahkan data santri, data nilai santri, dan nilai bobot kriteria. Sistem akan memberikan rekomendasi nama - nama santri berprestasi menggunakan metode AHP dan VIKOR. Kedua metode tersebut dikombinasikan, AHP untuk menghitung bobot kriteria dan VIKOR untuk melakukan perangkingan alternatif. Penggunaan dua metode tersebut bertujuan untuk saling melengkapi kekurangan dari masing - masing metode. Pengujian sistem menggunakan black box, uji sensitivitas nilai vikor, akurasi, recall, dan presisi. Pengujian dilakukan menggunakan data santri tahun lulusan 2015 2016 untuk jurusan IPA dan IPS. Berdasarkan pengujian sensitivitas nilai VIKOR, disimpulkan alternatif santri dengan NIS 150106 dan 150129 memiliki sensitivitas perubahan ketika nilai variabel $v$ diubah dengan menggunakan 0.4 dan 0.6. Hasil nilai rata - rata dari uji akurasi sebesar $90,5 \%$, nilai recall $87,5 \%$, dan nilai presisi $35 \%$.

Kata Kunci-AHP, Santri berprestasi, SPK, VIKOR.

\section{PENDAHULUAN}

Program Beasiswa Santri Berprestasi (PBSB) adalah program beasiswa khusus santri dari kementrian agama atau yang biasa disebut kemenag. PBSB adalah program positif diperluasnya akses santri santri guna melanjutkan studi sarjana dan profesi dengan program yang terbangun dimulai dari proses kerjasama, pengelolaan, seleksi, serta memberikan bantukan biaya bagi santri yang telah lulus dalam seleksi, sampai dengan pembinaan masa studi dan pembinaan pengabdian setelah lulus. Terhitung ada 18 perguruan tinggi yang telah menjadi mitra pada tahun 2019, diantaranya yaitu Universitas Gadjah Mada, UIN Syarif Hidayatullah, UIN Sunan Ampel, Institut Pertanian Bogor, Institut Teknologi Sepuluh Nopember [1].

Rekomendasi dari pihak sekolah diperlukan untuk santri - santri berprestasi mengikuti PBSB sehingga diharapkan peluang masuk bertambah besar. Kriteria yang dipakai untuk pemilihan santri berprestasi yakni disesuaikan dengan materi seleksi berkas PBSB. Materi untuk IPA adalah mencakup Kimia, Fisika, Biologi, Matematika dan Bahasa Inggris, sedangkan untuk IPS Ekonomi, Geografi, Sosiologi, Matematika, dan Bahasa Inggris.

Tidak adanya rekomendasi nama santri dari pihak sekolah untuk mengikuti PBSB dan sistem yang ada, selama ini pihak sekolah menunggu para santri untuk 
mengajukan pendaftaran PBSB. Proses mengikuti PBSB masih sebatas keinginan santri sendiri. Siapa yang ingin mengikuti, maka pihak sekolah memberi fasilitas bagi santrinya. Beasiswa ini begitu penting untuk para santri yang menginginkan melanjutkan pendidikannya ke perguruan tinggi ternama secara gratis. Sehingga para santri dapat melanjutkan pendidikan di perguruan tinggi ternama, membantu mereka yang termasuk keluarga kurang mampu dan mengubah citra pesantren pondok pesantren menjadi lebih berkualitas.

Penelitian oleh Simamora menggunakan metode VIKOR dalam merekomendasikan pemilihan televisi LED. Penilaian cukup baik pada uji kepuasan dengan nilai 0.72 menggunakan rumus Cronbach alpha [2]. Penelitian oleh Imanuwelita, dkk menggunakan dua model AHP dan VIKOR digunakan secara serial guna penelitian yang berjudul Penentuan Kelayakan Lokasi Usaha Franchise. AHP digunakan sebagai pembobot parameter atau kriteria dan metode VIKOR dipakai untuk pemeringkatan setelah kriteria dibobot oleh AHP. Tingkat akurasi dalam penelitian ini didapatkan hasil sebesar $80 \%$ [3].

AHP sendiri mempunyai beberapa kelemahan menurut ahli. Berikut ini dua kelemahan AHP. Pertama, keterikatan AHP dengan masukan utamanya. Masukan utamanya merupakan persepsi ahli, maka dari itu melibatkan subyektifitas ahli, metode dinilai tidak berarti jika sang ahli menilai penilaian yang tidak sesuai. Kedua AHP merupakan model matematis serta tidak adanya pengujian dengan statistik, maka dari itu tidak adanya batas kepercayaan kebenaran dari model yang sudah terbentuk [4]. Tetapi AHP mempunyai kelebihan uji konsistensi dalam menentukan nilai bobot kriteria, sehingga nilai bobot yang dihasilkan konsisten [3].

VIKOR memberi penilaian dengan solusi yang mendekati ideal, dimana setiap alternatif dipertimbangan dengan semua kriteria yang diusulkan dalam perangkingan. Tetapi VIKOR tidak memiliki pengujian dalam menentukan nilai bobot kriteria yang akan dipakai. Sehingga menjadi sebuah kelemahan bagi VIKOR. Untuk menutupi kekurangan tersebut maka dilakukan kombinasi dengan menggunakan AHP dalam menentukan nilai bobot kriteria.

Berdasarkan penelitian diatas, penelitian ini mengusulkan penggunaan medel AHP dan VIKOR untuk diterapkan dalam penentuan santri berprestasi. Diharapkan bisa memberikan solusi dalam pemeringakatan pemilihan santri berprestasi dan memberikan rekomendasi nama - nama santri berprestasi sehingga memberi kepuasan penggunaan sistem.

\section{LANDASAN TEORI}

\subsection{PBSB}

Program Beasiswa Santri Berprestasi (PBSB) adalah program beasiswa khusus santri dari kementrian agama atau yang biasa disebut kemenag. PBSB adalah program positif diperluasnya akses santri santri guna melanjutkan studi sarjana dan profesi dengan program yang terbangun dimulai dari proses kerjasama, pengelolaan, seleksi, serta memberikan bantukan biaya bagi santri yang telah lulus dalam seleksi, sampai dengan pembinaan masa studi dan pembinaan pengabdian setelah lulus.

2.2SPK

Sistem Pendukung Keputusan (SPK) merupakan sistem yang kebanyakan digunakan dalam komputer, yang dapat mendukung pengguna dalam penyelesaian soal atau masalah semi terstruktur dengan cara membantu pengambilan keputusan. Pengambilan keputusan, mengambil nilai data, yang kemudian diolah sehingga memberikan suatu rekomendasi dari informasi yang diperoleh.

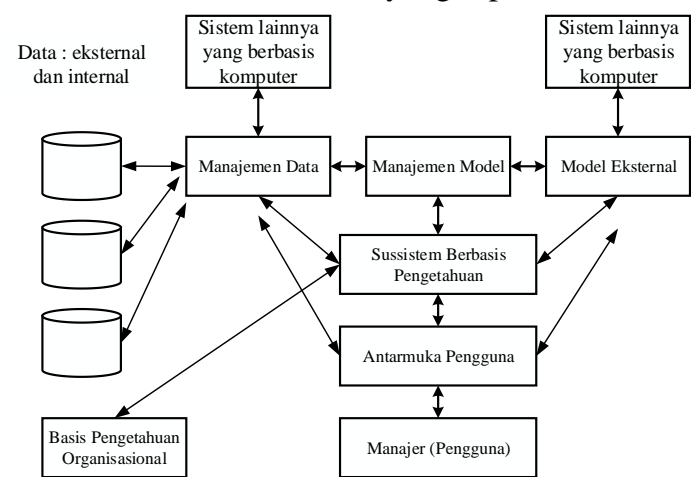

Gambar 1. Skematik Sistem Penunjang Keputusan [5]

1. Subsistem manajemen data, merupakan basis data bermuatan data penting guna

2. kondisi dan dikelola perangkat lunak disebut Database Mangement System

3. (DBMS).

4. Subsistem manajemen model, adalah bagian perangkat lunak di dalamnya

5. berisi model ilmu manajemen, keuangan, statistik, atau model kuantitatif yang

6. lainnya dimana menyampaikan kemampuan analitik dan manajemen perangkat

7. yang sesuai.

8. Subsistem manajemen pengetahuan. Mendukung keseluruhan bagian sistem

9. lain atau bekerja menjadi suatu komponen tersendiri. Subsistem

10.menyampaikan kecerdasan guna melebarkan kecerdasan dalam pengambil

11.keputusan.

12.Subsistem antarmuka pengguna. Subsistem ini berfungsi memberi jalan komunikasi dalam menggunakan SPK.

13.Manajer (user/pengguna). Pengetahuan manajer dalam pengatur dan yang menjalankan SPK, nantinya menentukan seberapa efektif penggunaan SPK itu sendiri [5].

\subsection{AHP}

Metoda Analytical Hierarchy Process (AHP) dikembangkan oleh Prof. Thomas Lorie Saaty dari Wharton Business School di awal tahun 1970, yang dimanfaatkan guna melakukan perangkingan atau pemerioritasan dari bermacam alternatif guna membantu memecahkan satu permasalahan. Seseorang dalam kehidupannya senantiasa akan 
dipertemukan dengan melakukan pilihan dari berbagai alternatif. Di sini perlu adanya melakukan pemerioritasan dan uji konsistensi kepada setiap pilihan yang sudah terlaksana. Di kondisi yang komplit, pengambilan keputusan akan dipengaruhi dengan banyak faktor. yang melingkupi keseluruhan tingkatan maupun keperluan.

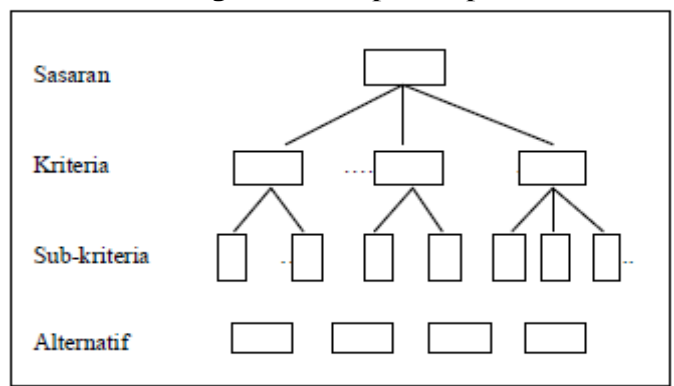

Gambar 2. Struktur hirarki dalam AHP [6]

\subsection{VIKOR}

VIKOR pertama kali dibangun dan dipublikasian oleh Opricovic \& Tzeng di tahun 1998. VIKOR berdasarkan arti leksikal mengandung arti optimalisasi bagian - bagian kriteria ke peringkat kompromi. VIKOR dimanfaatkan untuk menentukan urutan solusi peringkat, solusi kompromi, serta rentang konsistensi nilai bobot yang menjadi dasai untuk konsistensi solusi kompromi yang didapatkan dari nilai bobot asal. Inti pada VIKOR adalah membuat peringkat dan memilih solusi dari daftar alternatif yang kriteria rujukannya bernilai saling bertentangan. Memberikan peringkat kepada alternatif solusinya dirujukan kepada kadar kedekatan atas solusi ideal. Kelemahan VIKOR adalah tidak adanya uji konsistensi untuk penentuan bobot kriteria, bobot kriteria ditentukan dengan persepsi seorang ahli saja. Untuk menyempurkan VIKOR diperlukan metode lainnya sebagai pembobot dalam kriteria [3].

Metode TOPSIS dengan VIKOR berusaha dibandingkan dalam sebuah penelitian [7]. Pada penelitian tersebut menunjukkan bahwa hasil menggunakan metode VIKOR mempunyai nilai lebih mendekati solusi ideal dengan menggunakan cara normalisasi linear, sedangkan metode TOPSIS mempunyai keluaran yang menggunakan normalisasi vector.

Prosedur perhitungan metode VIKOR mengikuti tahap-tahap di bawah ini[3]:

a. Matriks Keputusan

Menyusun alternatif dan keriteria dengan mengikuti Persamaan (1).

$$
f_{i j}=\frac{x_{i j}}{\sqrt{\sum_{i=1}^{m} x_{i j}^{2}}} .
$$

Di mana $i$ merupakan alternatif ke 1,2,3,4 sampai dengan ke- $m, j$ adalah kriteria ke $1,2,3,4$, sampai dengan ke-n, $X i j$ adalah nilai elemen dari semua kriteria dan fij merupakan hasil normalisasi. Kemudian menghasilkan nilai keseluruhan elemen hasil normalisasi. Sesuai dengan persamaan (2).

$$
F=\left[\begin{array}{ccc}
f_{11} & \cdots & f_{1 n} \\
\vdots & \cdots & \vdots \\
f_{m 1} & \cdots & f_{m n}
\end{array}\right] .
$$

b. Nilai $\mathrm{F}$ maksimal $(f j *)$ dan $\mathrm{F}$ minimal $(f j-)$

Menentukan nilai Fmax $(f j *)$ dan $\operatorname{Fmin}(f j-)$ dari semua fungsi parameter, di mana $\forall j \in\{1,2,3,4 \ldots, n\}$. Menentukan nilai $f j *$ serta $f j-$ melakukan secara berderet dengan persamaan (3) serta (4).

$f_{j}^{*}=\max _{i} f_{i j}$......

$f_{j}^{-}=\max _{i} f_{i j}$.

Nilai Utility Measure (Ri)

Menghasilkan nilai $S i$ dan $R i$, dibutuhkan bobot kriteria. Bobot dari kriteria ( $w j$ ) bermaksud guna menyajikan kepentingan relatif. Nilai $S i$ serta $R i$ diakumulasi secara berderetan dengan persamaan (5) serta (6).

$$
\begin{aligned}
& S_{i}=\sum_{i=1}^{n} w_{j} \frac{\left(f_{j}^{*}-f_{i j}\right)}{\left(f_{j}^{*}-f_{j}^{-}\right)} \ldots . . . \\
& R_{i}=\max _{j}\left[w_{j} \frac{\left(f_{j}^{*}-f_{i j}\right)}{\left(f_{j}^{*}-f_{j}^{-}\right)}\right] . .
\end{aligned}
$$

d. Nilai VIKOR $(Q i)$

Untuk menghasilkan nilai VIKOR, nilai dari

\begin{tabular}{|c|c|c|}
\hline Si Max & $=$ & 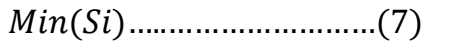 \\
\hline Si Min & $=$ & 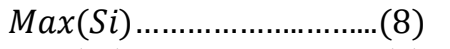 \\
\hline Ri Max & $=$ & 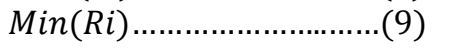 \\
\hline RiMin & $=$ & 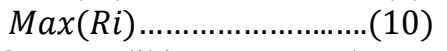 \\
\hline Nila & & OR dihitungan dengan \\
\hline
\end{tabular}
Si min, Si max, Ri min, dan Ri max bisa didapatkan melalui persamaan (7) sampai (12) sebagai berikut: menggunakan persamaan (13) dengan variaberl $\mathrm{v}$ bernilai default sebesar 0.5 .

$$
Q_{\mathrm{i}}=v \frac{\left(S_{\mathrm{i}}-s^{*}\right)}{\left(S^{-}-s^{*}\right)}+(1-v) \frac{\left(R_{\mathrm{i}}-R^{2}\right)}{\left(R^{-}-R^{*}\right)}
$$

e. Melakukan pemeringkatan nilai $\operatorname{VIKOR}(Q i)$

Pemeringkatan nilai $Q i$ dilaksanakan berdasarkan nilai terendah hingga yang terbesar (descending), dengan nilai terkecil merupakan kandidat terbaik. Yang nantinya mendapatkan hasil pemeringkatan.

f. Mengajukan pemenuhan kondisi $\mathrm{C} 1$ dan $\mathrm{C} 2$

Ketika C1 dan C2 memenuhi kondisi, maka solusi kompromi yang digunakan yaitu peringkat pertama hasil nilai VIKOR (Qi). Pemaparan $\mathrm{C} 1$ dan $\mathrm{C} 2$ adalah sebagaimana berikut [3]:

1)Kondisi C1 : "Penerimaan Keuntungan"

Kondisi CI terpenuhi jika peringkat alternatif kedua dikurangi dengan peringkat alternatif kedua, kemudian dibandingkan dengan nilai DQ. Jika hasil pengurangan lebih besar sama dengan DQ sesuai persamaan(14), maka C1 terpenuhi. Persamaan (15) cara mendapatkan nilai DQ.

$Q\left(a^{\prime \prime}\right)-Q\left(a^{\prime}\right) \geq D Q$.

$D Q=1 / m-1$

2)Kondisi C2 : "Penerimaan Stabilitas dalam Pendukung Keputusan" 
Kondisi C2 bisa terpenuhi jika nilai Q terpenuhi dalam nilai variable $\mathrm{v}$ yang berbeda. Nilai v akan dijelaskan sebagai berikut:

a) Dipilih "majority rule", jika $v>0,5$

b) Dipilih "consensus", jika $v \approx 0,5$

c) Dipilih "veto", jika $v<0,5$

Solusi kompromi yang lain akan diajukan jika C1 atau C2 tidak terpenuhi. Solusi kompromi sabagai berikut:

a) Jika kondisi C2 tidak dipenuhi, maka solusi kompromi adalah peringkat nilai nilai $\mathrm{Q}$ $a^{\prime}$ dan $a^{\prime \prime}$.

b) Jika C1 tidak dipenuhi, maka solusi kompromi adalah peringakt nilai Q $a^{\prime}, a^{\prime \prime}$, $a^{\prime \prime},, \ldots, a(m)$..

$Q(a(m))-Q\left(a^{\prime}\right)<D Q$

\section{METODOLOGI PENELITIAN}

Penelitian ini termasuk R\&D level ke 3 yang berarti meneliti dan mengembangkan produk yang telah ada dengan menggunakan langkah - langkah sesuai pada gambar berikut:

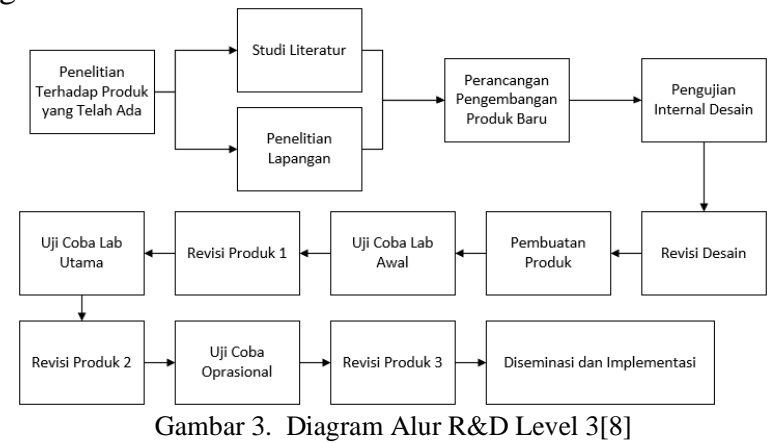

Namun penelitian ini menggunakan metode yang telah dimodifikasi karena waktu penelitian yang diberikan sangat terbatas. Penelitian membahas bagaimana suatu sistem pendukung keputusan akan merekomendasikan santri berprestasi dengan beberapa kriteria yang telah di tentukan di pondok pesantren Manba'ul Hikam. Berikut adalah metodologi penelitian:

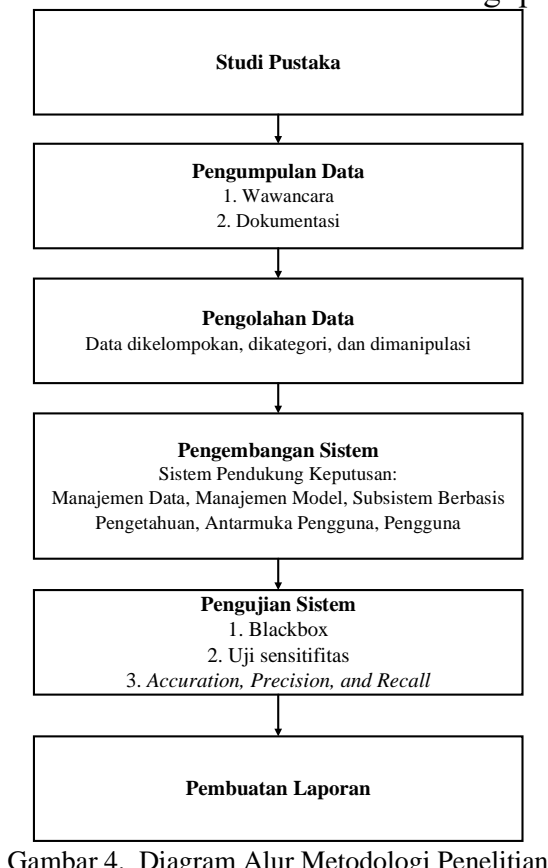

\section{HASIL DAN PEMBAHASAN}

4.1 Analisis

Tidak adanya rekomendasi nama santri dari pihak sekolah untuk mengikuti PBSB dan sistem yang ada selama ini pihak sekolah menunggu para santri untuk mengajukan pendaftaran PBSB. Proses mengikuti PBSB hanya sebatas keinginan santri sendiri. Dengan adanya sistem pendukung keputusan ini dapat membantu pihak sekolah merekomendasikan nama - nama santri untuk mengikuti PBSB. Banyaknya jumlah santri yang dibatasi paling banyak 10 orang oleh pihak sekolah.

\subsection{Pengolahan Data}

Data yang dibutuhkan adalah data santri beserta nilai akhir dari semester $1-5$. Nilai yang dibutuhkan adalah mata pelajaran yang diminta oleh PBSB untuk seleksi awal untuk ke tahapan selanjutnya yaitu: matematika, b. inggris, kimia, fisika, dan biologi untuk IPA, sedangkan matematika, b. inggris, geografi, ekonomi, dan sosiologi untuk IPS. Semua nilai dijumlahkan menurut mata pelajaran masing masing dari semester $1-5$.

Kemudian menentukan bobot kriteria menggunakan metode AHP, kriterianya adalah mata pelajaran yang telah disebutkan diatas, sesuai dengan jurusan. Selanjutkan perangkingan menggunakan metode VIKOR dengan nilai bobot kriteria yang telah dihasilkan dengan metode AHP.

\subsection{Hasil Perhitungan AHP dan VIKOR}

Berikut bobot kriteria hasil perhitungan dengan metode AHP dapat dilihat pada Tabel 1:

Tabel 1. Kriteria dan bobot

\begin{tabular}{llll}
\hline \multirow{2}{*}{ Jurusan } & \multicolumn{1}{c}{ IPA } & \multicolumn{1}{c}{ IPS } & Bobot \\
\hline \multirow{5}{*}{ Kriteria } & Matematika & Matematika & 0.285714 \\
& Kimia & Ekonomi & 0.142857 \\
& Fisika & Sosiologi & 0.142857 \\
& Biologi & Geografi & 0.142857 \\
& B. Inggris & B. Inggris & 0.285714
\end{tabular}

Perhitungan menggunakan metode AHP telah menghasilkan CR bernilai 0. Maka sesuai dengan rumus dalam AHP, bobot kriteria dianggap konsisten karena nilai CR kurang dari 0.1. AHP dipilih untuk pembobotan kriteria karena memiliki uji konsistensi, Langkah selanjutnya adalah melakukan pemeringkatan dengan menggunakan metode VIKOR.

1) Normalisasi Matriks Keputusan

Sesuai dengan rumus persamaaan (1), maka diperoleh hasil sebagaimana persamaan (2) hasilnya seperti pada Tabel 2 . 
Tabel 2. Normalisasi Matriks Keputusan

\begin{tabular}{cccccc}
\hline \hline NIS & Mtk & Kmia & Fsk & Bio & B.Ing \\
\hline 150101 & 77.6 & 77.6 & 77.6 & 77 & 78 \\
150102 & 75.6 & 75.8 & 77.8 & 76.2 & 78 \\
150103 & 76.4 & 75.4 & 77.8 & 76.8 & 76.2 \\
Dan seterusnya hingga alternatif terakhir & & \\
150139 & 79.2 & 82 & 79.4 & 82 & 84 \\
\hline \hline
\end{tabular}

2) Menentukan Nilai $\operatorname{Fmax}(f j *)$ dan $\operatorname{Fmin}(f j-)$ Menentukan Nilai $\operatorname{Fmax}(f j *)$ dan $\operatorname{Fmin}(f j-)$ menggunakan rumus pada persamaan (3) dan (4).

$f j * 1=\max \{f 1.1 ; f 2.1 ; f 3.1 ; f 4.1 ; \ldots . . f 39.1 ;\}$

$=\max \{77.6 ; 75.6 ; 76.4 ; 79 ; \ldots .79 .2\}$ $=91.2$

$f j * 1=\min \{f 1.1 ; f 2.1 ; f 3.1 ; f 4.1 ; \ldots . . f 39.1 ;\}$ $=\min \{77.6 ; 75.6 ; 76.4 ; 79 ; \ldots .79 .2\}$ $=75.6$

Perhitungan dilanjutkan hingga pada parameter terakhir. Jadi setiap parameter mempunyai nilai max dan min.

3) Nilai Utility Measure (Si) dan Regret Measure (Ri)

Untuk mendapatkan nilai Utility Measure (Si) menggunakan rumus pada persamaan (5) dan Regret Measure (Ri) padsa persamaan (6).

Guna mempermudah perhitungan rumus persamaan (5) dan (6) dipisahkan menjadi 4 rumus yaitu:

$\mathrm{Nij}=(\mathrm{f}+\mathrm{j}-\mathrm{fij}) /(\mathrm{f}+\mathrm{j}-\mathrm{f}-\mathrm{j})$

$\mathrm{N} 1,1=(91.2-77.6) /(91.2-75.6)$ $=0.871794872$

$\mathrm{N} 2,1=(91.2-75.6) /(91.2-75.6)$ $=1$

$\mathrm{N} 3,1=(91.2-76.4) /(91.2-75.6)$ $=0.948717949$

$\mathrm{N} 4,1=(91.2-79) /(91.2-75.6)$ $=0.782051282$

Dilanjutkan hingga alternatif terakhir.

$\mathrm{N} 39,1=(91.2-79.2) /(91.2-75.6)$ $=0.769230769$

Diteruskan dengan rumus yang sama untuk semua alternatif terakhir dan kriteria terakhir $(\mathrm{N} 39,5)$.

$\mathrm{F} * \mathrm{ij}=\mathrm{Nij} * \mathrm{wj}$

$\mathrm{F} * 1,1=0.871794872 * 0.285714286$ $=0.249084$

$\mathrm{F} * 2,1=1 * 0.285714286$ $=0.285714286$

$\mathrm{F} * 3,1=0.948717949 * 0.285714286$ $=0.271062271$

$\mathrm{F} * 4,1=0.782051282 * 0.285714286$ $=0.223443223$

Dilanjutkan hingga alternatif terakhir.

$\mathrm{F} * 39,1=0.769230769 * 0.285714286$ $=0.21978022$

Diteruskan dengan rumus yang sama untuk semua alternatif terakhir dan kriteria terakhir $\left(\mathrm{F}^{*} 39,5\right)$.

$\mathrm{Si}=\operatorname{sum}(\mathrm{F} * \mathrm{ij})$

$\mathrm{S} 1=0.249084249+0.121904762+0.136054422$

$+0.130252101+0.255462185$ $=0.892757718$
$\mathrm{S} 2=0.285714286+0.139047619+$

$0.132653061+0.138655462+0.255462185$ $=0.951532613$

$\mathrm{S} 3=0.271062271+0.142857143+0.132653061$

$+0.132352941+0.285714286$

$=0.964639702$

$\mathrm{S} 4=0.223443223+0.076190476+$ $0.081632653+0.109243697+0.218487395$ $=0.708997445$

Dilanjutkan hingga alternatif terakhir.

$\mathrm{S} 39=0.21978022+0.08+0.105442177+$ $0.077731092+0.154621849$

$$
=0.637575338
$$

Diteruskan dengan rumus yang sama untuk semua alternatif terakhir (S39).

$\mathrm{Ri}=\max (\mathrm{F} * \mathrm{ij})$

$\mathrm{R} 1=\{0.249084249 ; 0.121904762 ; 0.136054422$; $0.130252101 ; 0.255462185 ;$ $=0.255462185$

$\mathrm{R} 2=0.285714286 ; 0.139047619 ; 0.132653061$;

$0.138655462 ; 0.255462185$ $=0.285714286$

$\mathrm{R} 3=\{0.271062271 ; 0.142857143 ; 0.132653061$; $0.132352941 ; 0.285714286 ;$ $=0.285714286$

$\mathrm{R} 4=\{0.223443223 ; 0.076190476 ; 0.081632653 ;$ $0.109243697 ; 0.218487395 ;\}$

$$
=0.223443223
$$

Dilanjutkan hingga alternatif terakhir.

$\mathrm{R} 39=0.21978022+0.08+0.105442177+$ $0.077731092+0.154621849$ $=0.21978022$

Diteruskan dengan rumus yang sama untuk semua alternatif terakhir (R39).

4) Nilai VIKOR (Qi)

Mendapatkan nilai VIKOR (Qi) menggunakan rumus persamaan (11). Sebelum mengitung persamaan (11) diperlukan nilai $\max (\mathrm{Si}), \min (\mathrm{Si}), \max (\mathrm{Ri})$, dan $\min (\mathrm{Ri})$ sesuai dengan persamaan (7) (10).

$\mathrm{Q} 1=0.5 \quad[(0.892757718-0.024817927) /($ $0.964639702-0.024817927)]+(1-0.5)$ $[(0.255462185-0.021008403) /(0.285714286-$ $0.021008403)]$

$=0.904614794$

$\mathrm{Q} 2=0.5 \quad[(0.951532613-0.024817927) /($ $0.964639702-0.024817927)]+(1-0.5)$ $[(0.285714286-0.021008403) /(0.285714286-$ $0.021008403)]$

$=0.904614794$

$\mathrm{Q} 3=0.5[(0.964639702-0.024817927) /($ $0.964639702-0.024817927)]+(1-0.5)$ $[(0.285714286-0.021008403) /(0.285714286-$ $0.021008403)]$

$$
=1
$$

$\mathrm{Q} 4=0.5 \quad[(0.708997445-0.024817927) /($ $0.964639702-0.024817927)]+(1-0.5)$ $[(0.223443223-0.021008403) /(0.285714286-$ $0.021008403)]$ $=0.746371172$

Dan seterusnya hingga pada alternative terakhir. $\mathrm{Q} 39=0.5 \quad[(0.637575338-0.024817927) /($ $0.964639702-0.024817927)]+(1-0.5)$ $[(0.21978022-0.021008403) /(0.285714286 \quad-$ $0.021008403)]$

$=0.904614794$ 
Tabel 3. Perangkingan VIKOR $\left(\mathrm{Q}_{\mathrm{i}}\right)$ IPA

\begin{tabular}{ccc}
\hline \hline No & NIS & Nilai $(Q i)$ \\
\hline 1 & 150121 & 0 \\
2 & 150120 & 0.37896757747249 \\
3 & 150137 & 0.4012897947366 \\
4 & 150107 & 0.43413077952166 \\
5 & 150106 & 0.56315249671071 \\
6 & 150135 & 0.57452686504118 \\
7 & 150129 & 0.58087295917994 \\
Dan seterusnya hingga akhir & 1 \\
8 & 150103 & \\
\hline \hline
\end{tabular}

Tabel 4. Perangkingan VIKOR $\left(\mathrm{Q}_{\mathrm{i}}\right)$ IPS

\begin{tabular}{ccc}
\hline \hline No & NIS & Nilai $(Q i)$ \\
\hline 1 & 150214 & 0 \\
2 & 150225 & 0.27326220560916 \\
3 & 150211 & 0.27567532124104 \\
4 & 150237 & 0.50292609837471 \\
5 & 150234 & 0.54510416939241 \\
6 & 150236 & 0.56050623613514 \\
7 & 150223 & 0.57081938080996 \\
& Dan seterusnya hingga akhir \\
8 & 150218 & 1 \\
\hline \hline
\end{tabular}

Dari Tabel 3 dan 4 dapat diketahui hasil pemeringkatan. Urutan no $1-5$ adalah santri yang direkomendasikan sistem untuk mengikuti PBSB.

\subsection{Pengujian accuration, recall, dan precision}

Pengujian pertama dilakukan dengan menggunakan data tahun lulusan 2016 jurusan IPA yang berjumlah 39 santri. Kemudian dilakukan pengujian accuration, recall, dan precision dan mendapatkan nilai masing masing 92\%, 100\%, dan 20\%. Nilai hasil pengujian diartikan sebagai berikut:

1. Kedekatan nilai prediksi dengan nilai asli berada pada tingkat $92 \%$.

2. Berhasilnya sistem dalam ditemukannya kembali sebuah informasi berada pada tingkat $100 \%$.

3. Informasi yang diberikan sistem dengan yang diminta pengguna berada pada tingkat $20 \%$.

Pengujian pertama dilakukan dengan menggunakan data tahun ajaran 2016 jurusan IPS yang berjumlah 37 santri. Kemudian dilakukan pengujian accuration, recall, dan precision dan mendapatkan nilai masing masing $89 \%$, $75 \%$, dan $50 \%$.

1. Kedekatan nilai prediksi dengan nilai asli berada pada tingkat $89 \%$.

2. Berhasilnya sistem dalam ditemukannya kembali sebuah informasi berada pada tingkat $75 \%$.

3. Informasi yang diberikan sistem dengan yang diminta pengguna berada pada tingkat $50 \%$.
Tabel 5. Data real yang mengikuti PBSB dan rekomendasi sistem (IPA)

\begin{tabular}{rll}
\hline \hline NIS & \multicolumn{1}{c}{ PBSB } & SISTEM \\
\hline 150105 & Mengikuti & \\
150106 & Tidak mengikuti & Berprestasi \\
150107 & Tidak mengikuti & Berprestasi \\
150116 & Mengikuti & \\
150120 & Mengikuti & Berprestasi \\
150121 & Tidak mengikuti & Berprestasi \\
150126 & Mengkuti & \\
150133 & Mengikuti & \\
150137 & Tidak mengikuti & Berprestasi \\
\hline \hline
\end{tabular}

Tabel 6. Data real yang mengikuti PBSB dan rekomendasi sistem (IPS)

\begin{tabular}{rll}
\hline \hline NIS & \multicolumn{1}{c}{ PBSB } & SISTEM \\
\hline 150211 & Mengikuti & Berprestasi \\
150214 & Mengikuti & Berprestasi \\
150225 & Tidak mengikuti & Berprestasi \\
150230 & Mengikuti & \\
150231 & Mengikuti & \\
150232 & Mengikuti & \\
150234 & Mengikuti & Berprestasi \\
150237 & Tidak mengikuti & Berprestasi \\
& & \\
\hline \hline
\end{tabular}

Bahwa untuk pengujian accuration, recall, dan precision baik untuk jurusan IPA ataupun IPS, menunjukkan angka precision yang cukup rendah yaitu $20 \%$ untuk IPA dan 50\% untuk IPS. Berdasarkan hasil tabel 5 dan 6, dapat dilihat bahwa santri yang mengikuti PBSB pada tahun lulusan 2016 sebagian besarnya adalah santri yang dinyatakan oleh sistem tidak berprestasi. Karena di tahun sebelumnya tidak ada proses seleksi untuk mengikuti PBSB. Proses pendaftaran PBSB hanya berdasarkan pada keinginan santri, bukan berdasarkan pada prestasi santri. Hal ini mengakibatkan nilai precision menjadi cukup rendah.

4.5 Pengujian sensitifitas VIKOR

Tabel 7. Pengujian sensitivitas nilai VIKOR 0.4 dan 0.6 jurusan IPA

\begin{tabular}{ccc}
\hline \multicolumn{2}{c}{ jurusan IPA } & V 0.6 \\
\hline \multirow{2}{*}{ NIS } & V 0.4 & 0 \\
150121 & 0 & 0.3690468072527 \\
150120 & 0.38888834769228 & 0.38821442035059 \\
150137 & 0.41436516912262 & 0.41746487193393 \\
150107 & 0.45079668710939 & 0.56053961450799 \\
150106 & 0.56195870880528 & 0.5
\end{tabular}

Pengujian sensitivitas VIKOR dengan menggunakan nilai $\mathrm{v} 0.4$ mendapatkan hasil yang sama dengan nilai $\mathrm{v} 0.5$. Urutan yang diperoleh adalah 150121, 150120, 150137, 150107, dan 150106. Tetapi dengan menggunakan nilai $\mathrm{v} 0.6$ sedikit mendapatkan hasil yang berbeda. Perbedaan terdapat pada urutan ke 5 yaitu 150129 yang sebelumnya ditempati NIS 150106. 
Tabel 8. Pengujian sensitivitas nilai VIKOR 0.4 dan 0.6

\begin{tabular}{ccc}
\multicolumn{2}{c}{ jurusan IPS } \\
\hline \hline \multirow{2}{*}{ NIS } & \multirow{2}{*}{0.4} & V 0.6 \\
\hline 150121 & 0 & 0 \\
150120 & 0.38888834769228 & 0.3690468072527 \\
150137 & 0.41436516912262 & 0.38821442035059 \\
150107 & 0.45079668710939 & 0.41746487193393 \\
150106 & 0.56195870880528 & 0.56053961450799
\end{tabular}

\begin{abstract}
Pengujian sensitivitas VIKOR dengan menggunakan nilai $\mathrm{v} 0.4$ mendapatkan hasil yang sama dengan nilai $\mathrm{v} 0.5$. Urutan yang diperoleh adalah 150214, 150225, 150211, 150237, dan 150234. Tetapi dengan menggunakan nilai v 0.6 sedikit mendapatkan hasil yang berbeda. Perbedaan terdapat pada urutan ke 2 ke 3 yaitu 150211 yang sebelumnya ditempati NIS 150225 .

Hasil yang ditunjukkan pada tabel 7 dan 8 bahwa peringkat pertama tidak mengalami pergantian yang dikarenakan oleh perubahan nilai variable $v$.
\end{abstract}

\section{KESIMPULAN}

Kesimpulan hasil dari penelitian yang telah dilakukan adalah sebagai berikut :

1. Belum adanya rekomendasi nama santri untuk mengikuti PBSB oleh pihak sekolah, maka dibutuhkan rekomendasi santri berprestasi untuk beasiswa PBSB, agar semakin banyak peluang diterimanya santri dalam beasiswa tersebut. Perancangan sistem, peneliti menggunakan flowchart untuk menjelaskan alur proses pada sistem. Data flown diagram (DFD) untuk menjelaskan proses aliran data pada sistem. kemudian untuk alur penyimpanan data pada sistem peneliti menggunakan PDM (Physical Data Model) menjelaskan struktur penyimpanan data pada sistem. Setelah rancangan selesai dibuat maka dilanjutkan dengan pengembangan sistem.

2. Menggunakan data sebanyak 76 santri tahun lulusan 2016 untuk dilakukan pengujian. Dipisahkan dengan 2 jurusan yaitu IPA dan IPS yang masing - masing 39 dan 37 santri. Untuk IPA didapatkan NIS hasil rekomendasi dengan urutan dari peringkat pertama hingga kelima sebagai berikut: 150121, 150120 , 150137, 150107, dan 150106, sedangkan NIS untuk IPS sebagai berikut: 150214, 150225, 150211, 150237, dan 150234. Dilakukan beberapa pengujian:

a. Pengujian awal dengan melakukan perbandingan hitung hasil sistem dengan hitung manual, didapatkan hasil yang sama dari keduanya.

b. Pengujian hasil rekomendasi dengan menggunnakan accuration, recall dan presisi. Nilai yang didapatkkan dari pengujian jurusan IPA adalah accuration sebesar 92\%, recall sebesar 100\%, dan presisi sebesar $20 \%$. Sedangkan untuk IPS adalah adalah accuration sebesar $89 \%$, recall sebesar $75 \%$, dan presisi sebesar 50\%. Dari hasil presisi yang diperoleh $20 \%$ dan $50 \%$, presisi mendapatkan hasil yang cukup rendah dikarenakaan pada tahun sebelumnya tidak ada proses seleksi, sehingga semua santri bisa mengikuti PBSB, dari yang berprestasi ataupun tidak. Maka dapat diambil kesimpulan bahwa santri yang mengikuti PBSB sebagian besar adalah santri yang dinyatakan oleh sistem tidak berprestasi, sedangkan santri yang dinyatakan sistem berprestasi sebagian besar tidak mengikuti PBSB. Untuk recall mendapatkan hasil yang baik, dikarenakan jumlah rekomendasi sistem hamper sama dengan jumlah santri yang ikut PBSB.

3. Berdasarkan pengujian sesitivitas nilai VIKOR. Disimpulkan untuk jurusan IPA alternatif santri dengan NIS 150106 dan 150129 memiliki sensitivitas perubahan ketika nilai v diubah dengan menggunakan 0.4 dan 0.6. Sedangkan untuk jurusan IPS alternatif santri dengan NIS 150211 dan 150225 memiliki sensitivitas perubahan ketika nilai v diubah dengan menggunakan 0.4 dan 0.6.

Berdasarkan dari hasil penelitian yang dicapai, sistem rekomendasi pemilihan santri berprestasi masih terdapat kekurangan. Maka untuk itu penulis memberikan saran untuk memperbaiki kekurangan dalam sistem rekomendasi ini kepada peneliti selanjutnya. Saran sebagai berikut:

1. Menambakan parameter sepeti tingkat hafalan AlQuran para santri dan parameter lain yang berhubungan dengan PBSB agar didapatkan hasil yang lebih baik dalam perekomendasian nama santri untuk mengikuti PBSB.

2. Penggunaan metode selain AHP dan VIKOR untuk membandingkan hasil kombinasi metode AHP dan VIKOR dengan metode yang lain.

\section{REFERENSI}

[1] Kemenag, "Program Beasiswa Santri

Berprestasi (PBSB),” 2019. [Online]. Available: ditpdpontren .kemenag. go.id /pbsb/. [Accessed: 10-Apr-2019].

[2] B. Simamora, "Rancang Bangun Sistem Rekomendasi Televisi LED Dengan Metode Vikor Berbasis Web," vol. IX, no. 1, pp. 42-49, 2017.

[3] V. Imanuwelita, R. Regasari, M. Putri, and F. Amalia, "Penentuan Kelayakan Lokasi Usaha Franchise Menggunakan Metode AHP dan Penentuan Kelayakan Lokasi Usaha Franchise Menggunakan Metode AHP dan VIKOR," no. August 2017, 2018.

[4] H. Magdalena, "Sistem Pendukung Keputusan Untuk Menentukan Mahasiswa Lulusan Terbaik di Perguruan Tinggi (Studi Kasus STMIK Atma Luhur Pangkalpinang)," 2012, p. 8.

[5] E. Turban, J. E. Aronson, and T. P. Liang, Decision Support System and Intelligent Systems - 7 th ed. Pearson Education, Inc. Dwi Prabantini (penterjemah). 2005. Sistem Pendukung Keputusan dan Sistem Cerdas. Yogyakarta: Penerbit ANDI, 2005.

[6] T. L. Saaty, The Analytic Hierarchy Process. New York: McGraw-Hill, 1980. 
[7] S. Opricovic and G.-H. Tzeng, "Compromise solution by MCDM methods : A comparative analysis of VIKOR and TOPSIS," vol. 156, pp. 445-455, 2004.

[8] Sugiyono, Metode Penelitian dan Pengembangan Research and Development. Bandung: CV. Alfabeta, 2016. 